\title{
The Generic Attributes of the New Millennial Leaders*
}

\author{
Salina DAUD ${ }^{1}$, Wan Noordiana WAN HANAFI ${ }^{2}$
}

Received: September 01, 2020 Revised: October 26, 2020 Accepted: November 05, 2020

\begin{abstract}
As the millennials continue to mature and enter the workforce, it is important that employers understand what this generation expects from all aspects of their employment and leadership preferences in order to prepare them to be the next millennials leaders. The purpose of this research is to determine the generic attributes of the new millennial leaders in Malaysia. The survey is distributed among executives in the selected government-linked, multinational, and public-sector companies in Malaysia, with 237 (72\%) of whom being millennials. Partial least square (PLS-SEM) via software SmartPLS 3.0 was applied to evaluate the measurement model and the structural model. Results from this study indicate that the attributes of the millennials leader are innovative (0.213), inspiration (0.128), and visionary (0.122). Thus, organization can focus on those attributes in preparing the millennials for being the next generation of leaders. This study offers important implications to researchers as well as practitioners, and highlights the leadership attributes that could help in enhancing millennials leadership. This study produces a new millennials leadership attributes model for millennials leaders in Malaysian companies; with millennials becoming the fastest-growing age groups in the organizations, this study will promote effective and efficient skills for the millennials.
\end{abstract}

Keywords: Millennials, Leadership, Attributes, Diversity, Generations, Workforce, Structural Equation Model

JEL Classification Code: M10, M12, M14

\section{Introduction}

The generational differences are a legitimate diversity issue that organizations need to recognize and understand (Arsenault, 2004). Each generation is distinct, to some extent, in terms of their core values and work values (Salahuddin, 2010). Now, the silent generation and first wave of Baby Boomers are beginning to retire from the workplace, taking decades of valuable experience with them, while Generation $\mathrm{X}$ and millennials are becoming the fastest-growing age

\section{*Acknowledgements:}

Special thanks to Ministry of Higher Education (MOHE), Malaysia, for funding this research through Fundamental Research Grant Scheme (FRGS).

${ }^{1}$ First Author. Professor, College of Business Management and Accounting, Universiti Tenaga Nasional, Malaysia.

Email: salina@uniten.edu.my

${ }^{2}$ Corresponding Author. Post-Doctoral, College of Business Management and Accounting, Universiti Tenaga Nasional, Malaysia [Postal Address: Universiti Tenaga Nasional, Kampus Sultan Haji Ahmad Shah, Muadzam Shah, Pahang, 26700, Malaysia]

Email: diana.hanafi@uniten.edu.my

(C) Copyright: The Author(s)

This is an Open Access article distributed under the terms of the Creative Commons Attribution Non-Commercial License (https://creativecommons.org/licenses/by-nc/4.0/) which permits unrestricted non-commercial use, distribution, and reproduction in any medium, provided the original work is properly cited. group in the organizations and the next-generation of leadership (Cheng et al., 2015). Today's workplace shows an increasing number of Millennials entering the workforce.

According to CIA World Fact Book (2018), The total population of Malaysian aged 55 and above is at $8.27 \%$ and will increase to $14.5 \%$ in 2040 (Department of Statistics Malaysia, 2020). It shows that more senior employees (Baby Boomers, Generation X) in the workforce will leave the organizations rapidly due to retirement or voluntary resignation and hence organizations need to redefine their plan to retain good employees (Hossain et al., 2018). Other than that, according to the Malaysian Statistical Department (2018), millennials employees made up over $68 \%$ of the total workforce in Malaysia. Statistics by the U.S. Census Bureau also predicted that in 2030 , millennials will represent $75 \%$ of the global workforce and therefore the future of organizations is in their hands (Fubu, 2017; Huyler et al., 2015).

To date, there are numerous studies conducted on Malaysian millennials, however, they covered millennials' work motivation, values, behaviors, job satisfaction, and organizational commitment (Deal et al., 2010; Holt, 2018; Moreno et al., 2017). Most of the research also examined the leadership preferences of millennials, the differences between millennials and other generations, and the management preferences and practices of millennials in 
the general workforce (Graybill, 2014; Subramaniam \& Ramendran, 2017), but it does not focus on millennials' leadership attributes. Most research is carried out in the Western context, investigating Western samples by Western scholars. The findings from these studies may not be applicable to the Malaysian context (Sharkawi et al., 2016).

Leadership is the main weapon of the organization. Through leadership, managers can achieve the goals, productivity and labor productivity of the organizations (Suong \& Dao, 2019). Therefore, this brings forward the purpose of this study, which is to identify the generic attributes of Malaysian millennial leaders in the selected government-linked companies (GLCs), multinational companies (MNCs) and public-sector companies. It is hoped that this research will contribute to the knowledge and practices of encouraging leadership attributes among millennials leaders in Malaysian companies.

\section{Literature Review}

\subsection{Generation Cohorts}

According to Zemke (2001), generational differences are of importance to organizations as well as society because generations are rooted in different values, attitudes, ambitions and mindsets. Currently, there are three generational cohorts that are relevant in Malaysia today: Baby Boomers, Gen X, and Gen Y, which make up $29 \%, 34 \%$, and $34 \%$, respectively (Fry, 2015). As suggested by Muthu \& Ya Yee (2011), the generational differences between these three generations should be identified to eliminate failure to understand the demands of each generation that could lead to misunderstanding and conflict in organizations.

Recent studies have investigated diverse behaviors of people based on their generational cohort. Studies indicate that there is a notable difference in the behaviors of Baby Boomers, Gen X and Gen Y (Bathmanathan et al., 2018; de Waal et al., 2017; Williams \& Page, 2011). The authors assert that each generation must be treated differently according to their requirements, desires and specialties. The three generational cohorts are described in Table 1.

As this study focuses on millennials' leadership attributes, the section below will discuss the characteristics of millennials generation in more detail.

\subsection{Millennial}

The millennials generation is born between 1980 and 2000 and described as significantly different from previous generations currently in the workforce, namely, Baby Boomers and Generation X (Holt, 2018). Millennials are the first who grew up with globalization and digitalization and were raised by extremely involved parents in a safe environment. Millennials differ in the extent of responsibility, hierarchy, job security, flexibility and feedback they need in the workplace, compared to previous generations (Cahill \& Sedrak, 2012). Other key characteristics of this generation are that they view work as a source of revenue; they value a creative environment and recognition; workplace and time flexibility; and participative work style (Bathmanathan et al., 2018; Kultalahti \& Viitala, 2015; Strawser et al., 2018). It is widely known that millennials have their own set of values, expectations and perceptions of authority and the ideal work environment. According to Islam et al. (2011), the characteristics of the millennials are reported to have been influenced by leaders, development, technologies and trends of the time globally, but their behavior may vary by region depending on social and economic conditions. Other than that, unlike other generations, millennials' job satisfaction and workplace culture are not associated with their organizational commitment, however, their own performance and the organization retention program are the factor that keep them in the organization (Stewart et al., 2017).

Table 1: Generation Cohorts

\begin{tabular}{|l|c|l|}
\hline Generation & Year of Birth & \multicolumn{1}{c|}{ Description } \\
\hline Baby Boomer & $1946-1964$ & $\begin{array}{l}\text { The largest generation grew up in a time of economic prosperity. Their core values } \\
\text { include optimism, team orientation, personal gratification, health and wellness, } \\
\text { personal growth, youth, work and involvement (Hofstetter \& Cohen, 2014). }\end{array}$ \\
\hline Gen X & $1965-1979$ & $\begin{array}{l}\text { Gen X is reportedly self-oriented, cynical and materialistic. As a group, they are } \\
\text { waiting longer to marry; they want quality leisure time and do not easily submit to } \\
\text { authority. This generation wants to make an impact on society; they also need to } \\
\text { see that their accomplishments are valued and that they are part of their employers' } \\
\text { success (Mayer, Caruso, \& Salovey, 2016). }\end{array}$ \\
\hline Millennials & $1980-2000$ & $\begin{array}{l}\text { Millennials, often referred to as Generation Y, Nexters, or the Net-Generation is the } \\
\text { youngest generation in the current workforce (Sessa, Kabacoff, Deal, \& Brown, 2007). } \\
\text { Gilley, Waddell, Hall, Jackson, and Gilley (2015), list their core values as optimism, } \\
\text { civic duty, confidence, achievement, sociability, morality, street smarts and diversity. }\end{array}$ \\
\hline
\end{tabular}

Source: Rajan (2007) 


\subsection{Millennials' Leadership Attributes}

Leadership style is a form of leadership behavior that affects the activities of others and is considered an important management element (Doan et al., 2020). The study of leadership, like the study of generations, has been an important and central part of the literature on management and organizational behavior for several decades (Kraus, 2017). This study is using the definition from Pardesi and Pardesi (2013), leadership is the relationship between an individual and group who share common interests, where the individual determines and guides the group to behave in a certain manner. Leadership is the act of influencing a group to work together to set and achieve common goals (Pardesi \& Pardesi, 2013). It is becoming evident that a different kind of leadership is needed in the 21 st century, for it is an era of many complexities and challenges (Wan Noordiana et al., 2016).

Attributes of an effective leader must include believing in the possibility of success, good communication skills, empathy, energy, and sound judgment (Pardesi \& Pardesi, 2013). A leader with a positive attitude and mood will receive more employee buy-in and drive higher employee performance (Eberly \& Fong, 2013). Effective leadership helps workers to perform and fulfill the organization's needs. They would be able to communicate clearly the organization's mission, vision, goals and create innovation to provide a sustainable competitive advantage (Al-Khasawneh \& Moh'd Futa, 2013).

Different generations have different preferences or attributes for leadership. Growing up in a different world from baby boomers, millennials bring different values and expectations to the workforce (Ferri-Reed, 2012). Millennials tend to be more optimistic toward leadership and have stronger interest in leadership role (Faller \& Gogek, 2019). There are more millennials who consider themselves as leaders $(70.8 \%)$ compared to those who do not (Graybill, 2014). As millennials constitute the largest proportion in the workforce, therefore, it is important to understand what the millennials' leadership attributes are.

According to Paais et al. (2020) leadership in the organization needs to be owned by all internal members of the organization, regardless of its vision and mission. Ren et al. (2018) have identified several leadership attributes of millennials, namely, visionary, contingent rewards, inspiration, focus and collaborate. Shrivastava, et al. (2017), on the other hand, have identified two millennial leadership attributes, namely, inspiration and contingent rewards. This was supported by similar findings from de Waal et al. (2017), which highlighted that millennials have high preferences for contingent rewards. Aydogmus, et al. (2018) showed that millennials tend to have innovative ideas and they are easily mastering new technologies.
Other than that, Graybill (2014) has identified seven leadership attributes pointed out by millennials, namely, communication, respect, vision, influence, trust, integrity and teamwork. For Sharkawi et al. (2016), millennials have high preference for an approachable leader with vision and working in collaborative environment. Millennials are also likely to feel a certain freedom and, thus, be more creative in thought and innovative in action (Holt, 2018). Study by Dulin (2008) included qualitative research in the form of interviews with large focus groups exploring leadership preferences of millennials and found five attributes competence, interpersonal relations, management of others, self-management, and communication.

The ability to recognize and understand difference leadership attributes provides organizations and managers with an advantage in leading their diverse workforce effectively. They can also achieve more productivity and generate a competitive advantage, which benefits both the organization and the employees. Every leadership style has different attributes. Thus, in this study, from the discussion above, the millennials' leadership attributes used are vision, strategic thinking, focus, contingent reward, idealized influence, inspiration, collaborate, courage, intellectual stimulation, passion, willingness to change, and communication.

\section{Research Methods}

\subsection{Sample}

The respondent in this study are millennials from government-linked companies (GLCs), multinational companies (MNCs) and public-sector companies. The unit of analysis of this study is the individual who is millennials. The sample size is assessed using G*Power. With 13 predictors for the millennials' leadership attributes, a minimum sample size of 131 was needed to generate a power of 0.80 for the PLS model with 0.15 of medium effect size (Hair et al., 2019). Thus, with 237 respondents, our PLS model has met the minimum sample size requirement and generated more power.

\subsection{Measurement}

Millennials' leadership attributes were measured using 52 items adopted from Kim and Mauborgne (2017), Wan Noordiana et al. (2016), Kim and Mauborgne (2014) and Antonakis and House (2013). A 5-point Likert scale, ranging from 1 (strongly disagree), 2 (disagree), 3 (neutral), 4 (agree), to 5 (strongly agree) was applied. Thirteen dimensions were used to measure the millennials' leadership attributes. As highlighted above, all the selected items were validated by the literature. 


\subsection{Data Analysis}

Smart PLS was applied to evaluate the measurement model and structural model. PLS-SEM analysis was selected because it can assess all paths simultaneously, non-normal data, and new relationships (Hair et al., 2019; Ramayah et al., 2018). The present study aims to determine the generic attributes of millennials' leadership through a quantitative research method. A questionnaire was prepared based on the measures designed for each construct defined in the literature. In order to test the questionnaire, a pre-test was done through a focus group discussion. Four academics and six experts from the industry in the area of leadership, who were based in Malaysia, were approached to seek their views. From the focus group discussion comments, minor changes to the wording of the instrument were made.

\section{Results and Discussion}

\subsection{Demographic Profile of Respondent}

The respondents consist of 93 male $(39.2 \%)$ and 144 females $(60.8 \%)$. Since this study is focusing on millennials, all the respondents are age between 31 and 40 years old. In terms of race, the highest number of respondents is Malay, with a total number of $211(89.0 \%)$. As for marital status, from a total of 237 respondents, 138 respondents are single (58.2\%). The education level can be divided into four categories, which is STPM/diploma, bachelor degree, master degree and $\mathrm{PhD}$, where the highest number of respondents (164) have a bachelor degree (69.2\%). As for job positions, 126 respondents are senior executive (53.2\%). In terms of years of working, of 237 respondents, 167 respondents $(70.5 \%)$ have a working experience of less than five years, as for working experiences.

\subsection{Measurement Model Analysis}

For measurement analysis, the model needed to be evaluated in terms of the scales' reliability and validity (Hair et al., 2019). It is assessed by looking at indicator reliability, composite reliability, convergent validity (AVE), and discriminant validity (Heterotrait-monotrait ratio [HTMT] criterions) (Henseler et al., 2015). First the indicator reliability was checked by examining their factors loading. According to Hair et al. (2017), the factor loadings are acceptable between 0.600 to 0.700 for social science studies. In the present study, values greater than 0.700 were accepted. Based on this criterion, nine items, which are less than 0.700 are removed, namely, V2, CR7, ST27, ST28. ST29, F32, F35, CLBRTE37, and CLBRTE39 as the remaining indicators had appropriate loadings to remain in the model. Table 3 shows that all indicator loadings exceed the criterion of being greater than 0.700 , and no cases present loadings less than 0.700 . Thus, a total of 44 indicators out of the 52 initial items were kept, and these indicators were confirmed as accurate reflections of the defined constructs, thereby confirming the reliability of the measurement scale developed.

Second, composite reliability (CR) was used for internal consistency evaluation in the construct reliability. Table 3 shows that the CR for all constructs was greater than 0.700 . Thus, the CR showed that the scales were reasonably reliable and indicated that all the latent construct values exceeded the minimum threshold level of 0.700 . Third, to verify the convergent validity of the variables, each latent construct's Average Variance Extracted (AVE) was calculated (Fornell $\&$ Larcker, 1981). The lowest $50 \%$ of the variance from the observed variable should be taken by the latent constructs in the model. Hence, this indicates that the AVE for all constructs should be above 0.500 (Hair et al., 2011). From Table 4, it is seen that all the AVE values were more than 0.500 , so convergent validity was confirmed for this study model. These results confirmed the convergent validity and good internal consistency of the measurement model.

Fourth, to assess the discriminant validity and measure how different a construct is from another while identifying phenomena not represented by other constructs in the model, the HTMT criterion was used, as can be seen in Table 4. All values are below 0.90 and 0.85 (Hair et al., 2017; Henseler et al., 2015); therefore, the model satisfies this criterion.

\subsection{Structural model analysis}

After the measurement model was found to be valid and reliable, the structural model needed to be interpreted correctly. As the next step of the analysis, the guidelines, which are proposed by Hair et al. (2017), to assess the structural model are applied in this study. This procedure consists of the assessment of coefficient of determination $\left(\mathrm{R}^{2}\right)$, path coefficient and t-statistic value, and the predictive relevance of the model $\left(\mathrm{Q}^{2}\right)$, which are the key standards for evaluating the inner structural model.

To evaluate the structural models' predictive power, we calculated the $R^{2} . R^{2}$ measures the overall effect size and variance explained in the endogenous construct for the structural model and is thus a measure of the model's predictive accuracy (Ramayah et al., 2018). In this study, the inner path model was 0.793 , meaning that about $79.3 \%$ of the change in the millennial leadership attributes was due to the thirteen variables in the model (refer Table 6). According to Hair et al. (2017), $\mathrm{R}^{2}$ value of 0.75 is considered substantial, an $R^{2}$ value of 0.50 is regarded as moderate, and an $R 2$ value of 0.26 is considered as weak. Hence, the $\mathrm{R}^{2}$ value in this study is substantial. 
Table 3: Factor's loading

\begin{tabular}{|c|c|c|c|c|c|}
\hline Variable & Item Code & Loading & Variable & Item Code & Loading \\
\hline \multirow[t]{5}{*}{ Visionary } & V1 & 0.804 & \multirow[t]{5}{*}{ Strategic thinking } & ST27 & 0.548 \\
\hline & V2 & 0.507 & & ST28 & 0.445 \\
\hline & V3 & 0.836 & & ST29 & 0.521 \\
\hline & V4 & 0.838 & & ST30 & 0.872 \\
\hline & V5 & 0.759 & & ST31 & 0.899 \\
\hline \multirow[t]{4}{*}{ Contingent reward } & CR6 & 0.777 & \multirow[t]{5}{*}{ Focus } & F32 & 0.419 \\
\hline & CR7 & 0.317 & & F33 & 0.744 \\
\hline & CR8 & 0.849 & & F34 & 0.855 \\
\hline & CR9 & 0.758 & & F35 & 0.551 \\
\hline \multirow[t]{3}{*}{ Courage } & C10 & 0.724 & & F36 & 0.766 \\
\hline & C11 & 0.881 & \multirow[t]{4}{*}{ Collaborate } & CLBRTE37 & 0.482 \\
\hline & C12 & 0.865 & & CLBRTE38 & 0.871 \\
\hline \multirow[t]{4}{*}{ Idealized influences } & II13 & 0.707 & & CLBRTE39 & 0.406 \\
\hline & II14 & 0.823 & & CLBRTE40 & 0.838 \\
\hline & II15 & 0.848 & \multirow[t]{6}{*}{ Innovative } & INVTE41 & 0.759 \\
\hline & II16 & 0.791 & & INVTE42 & 0.770 \\
\hline \multirow[t]{4}{*}{ Inspiration } & 117 & 0.792 & & INVTE43 & 0.807 \\
\hline & $\mid 18$ & 0.878 & & INVTE44 & 0.788 \\
\hline & 119 & 0.835 & & INVTE45 & 0.773 \\
\hline & 120 & 0.790 & & INVTE46 & 0.738 \\
\hline \multirow[t]{3}{*}{ Intellectual stimulation } & IS21 & 0.790 & \multirow[t]{3}{*}{ Willingness to change } & WTC47 & 0.755 \\
\hline & IS22 & 0.869 & & WTC48 & 0.790 \\
\hline & IS23 & 0.854 & & WTC49 & 0.709 \\
\hline \multirow[t]{3}{*}{ Passion } & P24 & 0.775 & \multirow[t]{3}{*}{ Communication } & COM50 & 0.798 \\
\hline & P25 & 0.861 & & COM51 & 0.840 \\
\hline & P26 & 0.825 & & COM52 & 0.758 \\
\hline
\end{tabular}

Note: Bold figure shall be removed (V2, CR7, ST27, ST28. ST29, F32, F35, CLBRTE37, CLBRTE39).

Table 4: Internal Consistency Reliability Result

\begin{tabular}{|l|c|c|}
\hline Variable & CR & AVE \\
\hline Visionary & 0.793 & 0.562 \\
\hline Contingent reward & 0.838 & 0.633 \\
\hline Courage & 0.865 & 0.624 \\
\hline Idealized influences & 0.872 & 0.630 \\
\hline Inspiration & 0.894 & 0.680 \\
\hline Intellectual stimulation & 0.877 & 0.703 \\
\hline Passion & 0.861 & 0.674 \\
\hline
\end{tabular}

\begin{tabular}{|l|c|c|}
\hline Variable & CR & AVE \\
\hline Strategic thinking & 0.879 & 0.784 \\
\hline Focus & 0.832 & 0.624 \\
\hline Collaborate & 0.844 & 0.730 \\
\hline Innovative & 0.899 & 0.597 \\
\hline Willingness to change & 0.793 & 0.562 \\
\hline Communication & 0.873 & 0.730 \\
\hline
\end{tabular}


Table 4: Discriminant validity - HTMT Criterion

\begin{tabular}{|c|c|c|c|c|c|c|c|c|c|c|c|c|c|}
\hline & V & CR & C & II & I & IS & $\mathbf{P}$ & ST & $\mathbf{F}$ & CBRTE & INV & WTC & COMM \\
\hline \multicolumn{14}{|l|}{ v } \\
\hline CR & 0.491 & & & & & & & & & & & & \\
\hline C & 0.299 & 0.451 & & & & & & & & & & & \\
\hline II & 0.477 & 0.542 & 0.595 & & & & & & & & & & \\
\hline I & 0.454 & 0.610 & 0.638 & 0.763 & & & & & & & & & \\
\hline IS & 0.502 & 0.635 & 0.707 & 0.63 & 0.513 & 0.635 & & & & & & & \\
\hline $\mathbf{P}$ & 0.516 & 0.607 & 0.593 & 0.555 & 0.629 & 0.381 & & & & & & & \\
\hline ST & 0.512 & 0.747 & 0.469 & 0.626 & 0.374 & 0.701 & 0.400 & & & & & & \\
\hline$F$ & 0.564 & 0.624 & 0.838 & 0.595 & 0.635 & 0.607 & 0.747 & 0.674 & & & & & \\
\hline CBRTE & 0.474 & 0.875 & 0.609 & 0.847 & 0.649 & 0.686 & 0.595 & 0.636 & 0.691 & & & & \\
\hline INV & 0.492 & 0.847 & 0.632 & 0.447 & 0.384 & 0.838 & 0.536 & 0.847 & 0.632 & 0.609 & & & \\
\hline WTC & 0.370 & 0.691 & 0.569 & 0.443 & 0.421 & 0.674 & 0.519 & 0.707 & 0.510 & 0.674 & 0.348 & & \\
\hline СОМM & 0.374 & 0.585 & 0.432 & 0.617 & 0.533 & 0.632 & 0.498 & 0.55 & 0.561 & 0.399 & 0.585 & 0.569 & \\
\hline
\end{tabular}

Note: $V=$ Visionary, $C R=$ Contingent reward, $C=$ Courage, II= Idealized influence, I=Inspiration, IS=Intellectual stimulation, $\mathrm{P}=\mathrm{Passion}$, $\mathrm{ST}=$ Strategic thinking, F=Focus, CBRTE=Collaborate, INV=Innovative, WTC=Willingness to change, COMM=Communication.

The objective of this study is to identify the millennials' leadership attributes. The significance of weight of each indicator reveals the relative importance and the loading represents the absolute importance that can be examined through bootstrapping. The bootstrapping procedure requires cases of at least equal in number to original sample's observation. Next, the path coefficient and t-statistics value is analyses by running bootstrapping procedure in PLSSEM (Hair et al., 2019). Lohmöller (1989), recommended $>0.1$ weight for an indicator. The results reveal that the path coefficient is above the recommended value of 0.1 . Path coefficients represent the strength and direction of the relationship between the variables. When the path coefficient is positive, it indicates a positive influence; when is a negative value, it indicates a negative influence. Table 5 below shows the path coefficient of each attribute.

Lastly, findings from this study are also supported by the $\mathrm{Q}^{2}$ value Geisser (1983), of the predictive relevance. According to Hair et al. (2011), the $\mathrm{Q}^{2}$ value can be obtained through the blindfolding process. The test's results should be interpreted as follows: if $\mathrm{Q}^{2}>0$, the model has predictive capability, if $\mathrm{Q}^{2}<0$, the model has no predictive capability (Chin, 2010; Hair et al., 2011). After running the blindfolding procedure with an omission distance $\mathrm{D} 7$, the $\mathrm{Q}^{2}$ value of item are above zero with 0.309 , indicating the predictive relevance of the PLS path model (refer Table 5).

\section{Discussions, Implication and Future Research}

The result revealed the millennials' leadership attributes, as evidenced in Table 6; the three highest indicators are innovative (0.213), inspirational (0.128) and visionary (0.122). First, for innovation, the finding is in line with findings by Aydogmus et al. (2018), who stated that millennials tends to have innovative ideas and they are easily mastering new technologies. As increasing number of millennials are beginning to fill the void left by retiring baby boomers, the need for innovation will continue to rise.

Second, for inspiration, it is consistent with findings by Ren et al. (2018), Shrivastava et al. (2017), Salahuddin (2010), where they stated that millennials preferred to inspire others. Besides, leaders who lead by inspiration could inspire followers by providing meaning and purpose to the current goals, and by creating an attractive path toward achieving a goal (Sanner-Stiehr \& Reynolds Kueny, 2017). Lastly, for vision, the findings are in line with previous research by Markus (2016), Ren et al. (2018), and Graybill (2014), who they stated that millennials have a high preference for vision as, visionary leaders are not dependent on the organization for their sense of who they are and are more likely to make decisions based on values (Olaka et al., 2017). 
Table 5: Bootstrapping, $R^{2}$ and $Q^{2}$ Result

\begin{tabular}{|c|c|c|c|c|c|c|}
\hline & $\begin{array}{c}\text { Path } \\
\text { Coefficient }\end{array}$ & $\begin{array}{l}\text { Standard } \\
\text { Deviation }\end{array}$ & T -Value & Decision & $\mathbf{R}^{2}$ & $\mathbf{Q}^{2}$ \\
\hline $\begin{array}{l}\text { Visionary -> Millennial Leadership } \\
\text { Attributes }\end{array}$ & 0.122 & 0.012 & $10.037^{* *}$ & Accepted & \multirow[t]{13}{*}{0.793} & \multirow[t]{13}{*}{0.309} \\
\hline $\begin{array}{l}\text { Contingent reward -> Millennial } \\
\text { Leadership Attributes }\end{array}$ & 0.085 & 0.011 & $7.809^{* *}$ & Accepted & & \\
\hline $\begin{array}{l}\text { Courage -> Millennial Leadership } \\
\text { Attributes }\end{array}$ & 0.090 & 0.011 & $8.313^{\star *}$ & Accepted & & \\
\hline $\begin{array}{l}\text { Idealized influence -> Millennial } \\
\text { Leadership Attributes }\end{array}$ & 0.117 & 0.014 & $8.575^{\star *}$ & Accepted & & \\
\hline $\begin{array}{l}\text { Inspiration -> Millennial Leadership } \\
\text { Attributes }\end{array}$ & 0.128 & 0.011 & $11.106^{* *}$ & Accepted & & \\
\hline $\begin{array}{l}\text { Intellectual Stimulation -> Millennial } \\
\text { Leadership Attributes }\end{array}$ & 0.114 & 0.011 & $9.999^{* *}$ & Accepted & & \\
\hline $\begin{array}{l}\text { Passion -> Millennial Leadership } \\
\text { Attributes }\end{array}$ & 0.097 & 0.010 & $9.336^{\star \star}$ & Accepted & & \\
\hline $\begin{array}{l}\text { Strategic Thinking -> Millennial } \\
\text { Leadership Attributes }\end{array}$ & 0.104 & 0.010 & $10.029^{* *}$ & Accepted & & \\
\hline Focus -> Millennial Leadership Attributes & 0.121 & 0.013 & $9.524^{\star *}$ & Accepted & & \\
\hline $\begin{array}{l}\text { Collaborate -> Millennial Leadership } \\
\text { Attributes }\end{array}$ & 0.087 & 0.010 & $8.683^{* *}$ & Accepted & & \\
\hline $\begin{array}{l}\text { Innovative -> Millennial Leadership } \\
\text { Attributes }\end{array}$ & 0.213 & 0.014 & $15.131^{* *}$ & Accepted & & \\
\hline $\begin{array}{l}\text { Willingness to change -> Millennial } \\
\text { Leadership Attributes }\end{array}$ & 0.076 & 0.011 & $6.776^{\star \star}$ & Accepted & & \\
\hline $\begin{array}{l}\text { Communication -> Millennial Leadership } \\
\text { Attributes }\end{array}$ & 0.091 & 0.010 & $8.851^{* *}$ & Accepted & & \\
\hline
\end{tabular}

Note: $t$-value more than 1.645 at ${ }^{*} p<0.05$, t-value more than 2.33 at ${ }^{* *} p<0.01$.

The findings have also revealed that the lowest number of path coefficient is on willingness to change $(0.076)$, since human needs are constantly changing or shifting to new needs, we are always required to change. Besides, organizations across all sectors are implementing new technologies and work practices. Change is an integral part of working life and cannot be viewed as something that happens every now and then (Dawson \& Andriopoulos, 2014). Willingness to change has the lowest number of path coefficients. This does not mean it is not important as millennials are also constantly changing with the environment, it means this attribute is least important compare to other attributes.

This study has some practical implications. Millennials' characteristics, which are unique and different from prior generations, pose challenges and opportunities for modern organizations. Organizations that can overcome challenges and leverage opportunities will have better chances to be successful and outperform their competitors. In order to do so, organizations need to create a leadership strategy, which will be optimum for millennial employees. Thus, from the findings of this study, organizations should focus on the top three attributes with the highest number of path coefficients. By focusing on those attributes, organizations can conduct training related to the attributes.

The study also makes some recommendations: (i) the data for this study were gathered from 237 millennials employees from government-linked companies (GLCs), multinational companies (MNCs) and public-sector companies in Malaysia, it is suggested that the sample size can be increased. Applying these results to different cultural contexts and populations may require appropriate alterations, (ii) further studies can advanced the current leadership attributes by studying Generation Z, which is the generation born after the millennials, as they are starting to enter the workplace. As previous studies have already indicated, generational differences may play an important 
role in leadership research (Anderson et al., 2017). Like the millennials, Generation $\mathrm{Z}$ might have unique characteristics that cannot be efficiently accommodated by the current leadership attributes, (iii) the empirical model developed for this study should be assessed for its validity across different Malaysian industries.

\section{Conclusions}

The findings of the study can provide insights to millennials leaders in promoting best practices in Malaysian companies. Even though the findings regarding the leadership style preference of each generation are not as conclusive as expected, it can be concluded that millennials tend to prefer innovative, inspiration and visionary leadership attributes. The ability to recognize and understand generational differences and leadership style preferences provides organizations and managers with an advantage in leading their diverse workforce effectively. Thus, they can achieve more productivity and generate a competitive advantage, which benefit both the organization and the employees.

\section{References}

Al-Khasawneh, A. L., \& Moh'd Futa, S. (2013). The impact of leadership styles used by the academic staff in the Jordanian public universities on modifying students' behavior: A field study in the northern region of Jordan. International Journal of Business and Management, 8(1), 1.

Anderson, H. J., Baur, J. E., Griffith, J. A., \& Buckley, M. R. (2017). What works for you may not work for (Gen) Me: Limitations of present leadership theories for the new generation. The Leadership Quarterly, 28(1), 245-260.

Antonakis, J., \& House, R. J. (2013). The full-range leadership theory: The way forward. In Transformational and Charismatic Leadership: The Road Ahead 10th Anniversary Edition. Bingley, UK: Emerald Group Publishing Limited.

Arsenault, P. M. (2004). Validating generational differences. Leadership \& Organization Development Journal, 25(2), 124-141.

Aydogmus, C., Camgoz, S. M., Ergeneli, A., \& Ekmekci, O. T. (2018). Perceptions of transformational leadership and job satisfaction: The roles of personality traits and psychological empowerment §. Journal of Management \& Organization, 24(1), 81-107.

Bathmanathan, V., Rajadurai, J., \& Sohail, M. S. (2018). Generational consumer patterns: A document analysis method. Global Business and Management Research, 10(3), 958-970.

Cahill, T. F., \& Sedrak, M. (2012). Leading a multigenerational workforce: Strategies for attracting and retaining millennials. Frontiers of Health Services Management, 29(1), 3-15.
Cheng, W. H., Tantasuntisakul, W., \& Md Isa, F. (2015). A comparison of factors influencing Malaysia and Southern Thailand women entrepreneurs' success. Australian Journal of Basic and Applied Sciences, 9(13), 135-139.

Chin, W. W. (2010). How to write up and report PLS analyses. In: Handbook of partial least squares (pp. 655-690). Berlin, Germany: Springer.

Dawson, P., \& Andriopoulos, C. (2014). Managing change, creativity and innovation. London, UK: Sage Publications.

de Waal, A., Peters, L., \& Broekhuizen, M. (2017). Do different generations look differently at high performance organizations? Journal of Strategy and Management, 10(1), 86-101.

Deal, J. J., Altman, D. G., \& Rogelberg, S. G. (2010). Millennials at work: What we know and what we need to do (if anything). Journal of Business and Psychology, 25(2), 191-199.

Doan, T. T. T., Nguyen, L. C. T., \& Nguyen, T. D. N. (2020). Emotional Intelligence and Project Success: The Roles of Transformational Leadership and Organizational Commitment. Journal of Asian Finance, Economics, and Business, 7(3), 223-233. https://doi.org/10.13106/jafeb.2020.vol7.no3.223

Dulin, L. (2008). Leadership preferences of a generation Y cohort: A mixed-methods investigation. Journal of Leadership Studies, 2(1), 43-59.

Eberly, M. B., \& Fong, C. T. (2013). Leading via the heart and mind: The roles of leader and follower emotions, attributions and interdependence. The Leadership Quarterly, 24(5), 696-711.

Faller, M., \& Gogek, J. (2019). Break from the past: survey suggests modern leadership styles needed for millennial nurses. Nurse Leader, 17(2), 135-140.

Ferri-Reed, J. (2012). Three ways leaders can help millennials succeed. The Journal for Quality and Participation, 35(1), 18.

Fornell, C., \& Larcker, D. F. (1981). Evaluating structural equation models with unobservable variables and measurement error. Journal of Marketing Research, 18(1), 39-50.

Fry, R. (2015). Millennials surpass Gen Xers as the largest generation in US labor force. Pew Research Center, 11. Retrieved July 2, 2020 from https://www.pewresearch.org/fact-tank/2018/04/11/ millennials-largest-generation-us-labor-force/

Fubu, T. (2017). Managing the Millennials. HR Future, 2017(Sep 2017), 16-17.

Geisser, S. (1983). On the prediction of observables: a selective update. Doctorate Dissertation, University of Minnesota

Gilley, A., Waddell, K., Hall, A., Jackson, S. A., \& Gilley, J. W. (2015). Manager behavior, generation, and influence on worklife balance: An empirical investigation. Journal of Applied Management and Entrepreneurship, 20(1), 3.

Graybill, J. O. (2014). Millennials among the professional workforce in academic libraries: Their perspective on leadership. The Journal of Academic Librarianship, 40(1), 10-15.

Hair, Matthews, L. M., Matthews, R. L., \& Sarstedt, M. (2017). PLS-SEM or CB-SEM: updated guidelines on which method to 
use. International Journal of Multivariate Data Analysis, 1(2), 107-123.

Hair, Ringle, \& Sarstedt. (2011). The Use of Partial Least Squares (PLS) to Address Marketing Management Topics: From the Special Issue Guest Editors Journal of Marketing Theory and Practice, 18(2), 135-138.

Hair, Risher, J. J., Sarstedt, M., \& Ringle, C. M. (2019). When to use and how to report the results of PLS-SEM. European Business Review, 31(1), 2-24.

Henseler, Ringle, C. M., \& Sarstedt, M. (2015). A new criterion for assessing discriminant validity in variance-based structural equation modeling. Journal of the Academy of Marketing Science, 43(1), 115-135.

Hofstetter, H., \& Cohen, A. (2014). The mediating role of job content plateau on the relationship between work experience characteristics and early retirement and turnover intentions. Personnel Review, 43(3), 350-376.

Holt, S. (2018). Engaging generation y: The millennial challenge. In: Engaged leadership (pp. 211-222): Springer.

Hossain, M. I., Limon, N., Amin, M. T., \& Asheq, A. S. (2018). Work Life Balance Trends: A Study on Malaysian GenerationY Bankers. IOSR Journal of Business and Management, 20(9), 01-09.

Huyler, D., Pierre, Y., Ding, W., \& Norelus, A. (2015). Millennials in the workplace: positioning companies for future success. SFERC 2015, 114.

Islam, M. A., Jantan, A. H., Hashim, H., \& Chong, C. W. (2011). Organisational culture and the millennials intention to stay: the mediating role of leadership management practices.

Kim, \& Mauborgne. (2014). Blue ocean leadership. Harvard Business Review, 92(5), 60-72.

Kim, \& Mauborgne. (2017). Blue Ocean Strategy with Harvard Business Review Classic Article "Blue Ocean Leadership". Boston, MA: Harvard Business Press.

Kraus, M. (2017). Comparing Generation X and Generation Y on their preferred emotional leadership style. Journal of Applied Leadership and Management, 5, 62-75.

Kultalahti, S., \& Viitala, R. (2015). Generation Y-challenging clients for HRM? Journal of Managerial Psychology, 30(1), 101.

Lohmöller, J.-B. (1989). Predictive vs. structural modeling: Pls vs. $\mathrm{ml}$. In: Latent variable path modeling with partial least squares (pp. 199-226). Berlin, Germany: Springer.

Mayer, J. D., Caruso, D. R., \& Salovey, P. (2016). The ability model of emotional intelligence: Principles and updates. Emotion Review, 8(4), 290-300.

Moreno, F. M., Lafuente, J. G., Carreón, F. Á., \& Moreno, S. M. (2017). The characterization of the millennials and their buying behavior. International Journal of Marketing Studies, 9(5), 135-144.
Muthu, K., \& Ya Yee, T. (2011). An Analysis on Workplace Expectations Among the White Collar Employees Across Baby Boomers, Gen X and Gen Y in Malaysia. Paper presented at the Society of Interdisciplinary Business Research (SIBR) 2011 Conference on Interdisciplinary Business Research.

Olaka, M. H., Lewa, P., \& Kiriri, P. (2017). Strategic leadership and strategy implementation in commercial banks in Kenya. Journal of Strategic Management, 2(1), 70-91.

Paais, M., Pattiruhu, J. R., Sopiah, S., Kurniawaan, D. T., Nora, E., \& Narmaditya, B. S. (2020). Effect of Motivation, Leadership, and Organizational Culture on Satisfaction and Employee Performance. Journal of Asian Finance, Economics and Business, 7(8), 577-588. https://doi.org/10.13106/jafeb.2020. vol7.no8.577

Pardesi, Y. Y., \& Pardesi, Y. (2013). Charismatic leadership: A critical analysis. The Government-Annual Research Journal of Political Scienc, 2(2).

Rajan, S. (2007). The changing face of the oilfield worker: Preparing for Generation Y. Paper presented at the Asia Pacific Oil and Gas Conference and Exhibition.

Ramayah, T., Cheah, J., Chuah, F., Ting, H., \& Memon, M. (2018). Partial least squares structural equation modeling (PLS-SEM) using SmartPLS 3.0. In: An Updated Guide and Practical Guide to Statistical Analysis. London, UK: Pearson.

Ren, S., Xie, Y., Zhu, Y., \& Warner, M. (2018). New generation employees' preferences towards leadership style in China. Asia Pacific Business Review, 24(4), 437-458.

Salahuddin, M. M. (2010). Generational differences impact on leadership style and organizational success. Journal of Diversity Management, 5(2).

Sanner-Stiehr, E., \& Reynolds Kueny, C. (2017). From the topdown: Transformational leadership considerations for health care organizations. Psychological Science Faculty Research paper, Missouri University of Science and Technology.

Sessa, V. I., Kabacoff, R. I., Deal, J., \& Brown, H. (2007). Generational differences in leader values and leadership behaviors. The Psychologist-Manager Journal, 10(1), 47-74.

Sharkawi, S., Mohamad, S., \& Roslin, R. (2016). Exploring the Leadership Preference of Malaysian Generation Y Employees: A Conceptual Paper. International Journal of Business and Management, 11(8), 152-161.

Shrivastava, P., Ikonen, M., \& Savolainen, T. (2017). Trust, leadership style and generational differences at work-a qualitative study of a threegeneration workforce from two countries. Nordic Journal of Business, 66(4), 257-276.

Stewart, J. S., Oliver, E. G., Cravens, K. S., \& Oishi, S. (2017). Managing millennials: Embracing generational differences. Business Horizons, 60(1), 45-54.

Strawser, M. G., Coffey, L., \& Martin, J. (2018). Millennial Cultural Transitions. Examining Millennials Reshaping Organizational Cultures: From Theory to Practice, 175. 
Subramaniam, S., \& Ramendran, C. (2017). Intention To Leave Among Generation Y Academicians In Private Universities. Universiti Sains Malaysia, Malaysia.

Suong, H. T. T., \& Dao, T. T. X. (2019). The impact of leadership styles on the engagement of cadres, lecturers and staff at public universities-Evidence from Vietnam. Journal of Asian Finance, Economics and Business, 6(1), 273-280. http://doi. org/10.13106/jafeb.2019.vol6.no1.273
Wan Noordiana, W., Salina, D., \& Nur Liyana, B. (2016). Blue ocean leadership determinants. International Journal of Management and Applied Science, 2(1), 72-75.

Williams, K. C., \& Page, R. A. (2011). Marketing to the generations. Journal of Behavioral Studies in Business, 3, 1.

Zemke, R. (2001). Here come the millennials. Training, 38(7), 44-49. 